\title{
AN INTEGRATING STUDY OF GENETIC DIVERSITY AND ECOLOGICAL NICHE MODELLING IN SALVIA ARISTATA (LAMIACEAE)
}

\author{
F. MoeIN ${ }^{1}$, Z. JAMZAD ${ }^{2}$ and M. RAHIMINEJAD ${ }^{1 *}$ \\ ${ }^{1}$ Department of Biology, Faculty of Science, University of Isfahan, Iran \\ E-mails: fatemeh.moein@gmail.com, *mrr@sci.ui.ac.ir, “mrrsci@gmail.com \\ ${ }^{2}$ Department of Botany, Research Institute of Forest and Rangelands, Tehran, Iran \\ E-mail: jamzad@rifr-ac.ir
}

(Received 24 January, 2018; Accepted 22 August, 2018)

\begin{abstract}
Applying both molecular data and ecological niche modelling is essential to infer the speciation mechanism and species delimitation in organisms. Salvia aristata Auch. ex Benth is an endemic species restricted to western, northwestern and centre of Iran and eastern parts of Turkey with variations in morphological character along its distributions. In this study, we applied SRAP marker and ecological niche modelling using climatic and geographic data to detect and examine the genetic structure and niche differentiation in $S$. aristata accessions. SRAP marker's results showed 242 bands highly polymorph. Genetic distance analysis provided two main clusters. The STRUCTURE analysis provided two distinct ecotypes $(K=2)$. Our ecological niche model produced good results with high performance based on area under curve (AUC > 0.9) for both ecotypes. Altitude was the most important variable contributing in niche model of both ecotypes. The niche space of both ecotypes is different based on niche identity test and background test as well. Based on genetic and ecological evidence, it is concluded that $S$. aristata gene pool underwent a parapatric speciation process caused by niche divergence and reproductive isolations as a consequence of divergent selection on floral traits.
\end{abstract}

Key words: ecological niche modelling (ENM), genetic structure, Salvia

\section{INTRODUCTION}

Generally, a species is considered as the fundamental unit in almost all biological fields such as systematic, ecology and conservation biology (De Queiroz 2007). Identifying the accurate boundaries of a species is critical to have a better perspective of any biological studies. Therefore, species delimitation is a subject of extensive part of studies in the framework of biology (Rissler and Apodaca 2007, Rivera et al. 2011, Zheng et al. 2017). However, defining the criterion which could address the boundaries of species is different and the place of debates (Levin 2000). Integrating morphological, genetic and ecological criteria proved to be helpful not only for resolving taxonomic confusions (De Queiroz 2007, DeSalle et al. 2005, Fujita et al. 2012), but also is mainly useful for interpreting the concurrent geographical patterns of pheno- 
typic and genotypic variations on special adaptive traits (Levin 2000, Richardson and Urban 2013).

To examine the veracity of species limits based on genetic data, different PCR based methods such as AFLP (amplified fragment length polymorphism), RAPD (random amplified polymorphism DNA) and ISSR (inter simple sequence repeat) are applied (Nguyen and Wu 2005, Penner et al. 1993, Vos et al. 1995). Although these methods produce useful data, they have some technical limitations. For instance, reproducibility of RAPD data is poor, AFLP method is expensive and ISSR could not produce enough polymorphic fragments in some plant groups (Robarts and Wolfe 2014). Sequence-related amplified polymorphism (SRAP) is a marker which amplifies open reading frames (ORFs) with specific forward and reverse primers. Compared with the other dominant markers, simplicity, reproducibility, cost effectiveness and high throughput of SRAP make it more applicable in the genomic studies (Chang et al. 2012, Li and Quiros 2001, Li et al. 2015, Robarts and Wolfe 2014). According to the previous studies, SRAP marker is very successful for detecting inter- and intra-population genetic variations (Erbano et al. 2015, Robarts and Wolfe 2014, Talebi et al. 2015). Not only integrating morphological information with genetic data is a powerful tool in interpretation of speciation trends, adaptive radiation and many other evolutionary aspects is helpful for evaluation of lower levels of systematic classification among organisms displaying non-powerful diagnostic morphological characters and endemism patterns.

The integration of ecological niche modelling with genetic data can reveal the influence of abiotic factors (precipitation, temperature and seasonality) on the processes involved in genetic structuring of organisms (AlvaradoSerrano and Knowles 2014, Knowles et al. 2007, Rissler and Apodaca 2007). Ecological niche modelling (ENM; also referred to as species distribution modelling [SDM]) uses species occurrence records in the form of GIS coordinates in combination with environmental variables (climatic or geospatial) to determine quantitatively the potential area of a species' or population's distributions (Kozak et al. 2008, Marchant et al. 2016, Raxworthy et al. 2007, Zhang et al. 2014). Different approaches and algorithms have been developed to predict species distributions (BIOCLIM: Busby 1991; GARP: Stockwell 1999; MAXENT: Phillips et al. 2006; BIOMOD: Thuiller et al. 2009). These tools are different in implemented method, treating occurrence records (presenceonly or presence/absence) and the ability to generating continuous or discrete predictions of habitat suitability. Specific research aims and the domain of any given study determines which methods are most appropriate (AlvaradoSerrano and Knowles 2014).

ENM methods have not only been applied broadly to evaluate the effect of climate change on species distribution (Guisian and Thuiller 2005), but another frequent use has been in the context of species delimitation (Anacker 
and Strauss 2014, Pelletier et al. 2015, Reeves and Richards 2011, Zheng et al. 2017). ENMs have been successfully been integrated with genetic data to test whether the niches of putative populations or species are similar or different. Where niche divergence coincides with the incomplete separation of species or populations (i.e. divergence with some degree of gene flow) and with divergent selection on reproductive morphological traits, different stages of divergence among the populations or species (ecotypes, subspecies and new specie) through the time will be expected (Nosil and Sandoval 2008, Rundle and Nosil 2005).

Salvia L. is known as the largest genus in Lamiaceae (Mentheae-Salviinae) with approximately 1000 species diversified in three regions of the world: Central and South America (500 spp.), Western Asia (200 spp.) and Eastern Asia (100 species) (Walker et al. 2004). Iran having 19 endemic species out of 61 is regarded as one of the important regions for Salvia diversity in Southwest Asia (Jamzad 2012).

S. aristata Auch. ex Benth. as the subject of this study is a perennial plant, 30-60 cm high, covered with short glandular and eglandular villose hairs; calyx campanulate with three upper teeth (median tooth is reduced in some populations). This plant is an endemic species restricted to West, Northwest and Centre of Iran (Jamzad 2012) and East of Turkey (Behçet and Avlamaz 2009).

During our field work and herbarium studies, we realised that there is a significant variation regarding both vegetative and reproductive characters in S. aristata forming different morphological variants (Jamzad 2012). Leaf blade varies from sub entire to imparipinnate with variation in leaflets' dimensions among the accessions examined. In flowers, presence or absence of traits such as annulus within the corolla tube, middle tooth in upper calyx were observed as well. In addition, the length of the calyx and pedicle ranges from 20-35 and 18-25 mm, respectively. Since S. aristata was first published (Bentham 1848), a long list of synonyms (S. sulcata Parsa, S. owerini Trautv. S. aristata var. viscida Bornm., Polakia paradoxa Stapf, S. anisodonta Hausskn. et Briq. ex Hausskn, S. garrousii Parsa, S. pinnatifolia Parsa) were known under this species (Hedge 1982, Jamzad 2012). This is a clear reflection of the morphological variations encountered within the domain of $S$. aristata. These taxonomic confusions and morphological variations motivated us to investigate the influence of genetic composition and ecological influences on these morphological variations.

This study is focused on the integration of the ecological niche modelling and genetic structure data to evaluate the influence of genetics and ecology on S. aristata phenotypic variations and inferring the mechanism of speciation involved in. To the best of our knowledge, this is the first study of investigating the influence of genetic data and ecology on phenotypic variation in south western Asian Salvia. 


\section{MATERIALS AND METHODS}

A total of 25 specimens of S. aristata collected from 1987 to 2009 kept in TARI herbarium were used in this study (Table 1). Since the natural populations are normally formed from a few and scattered individuals our sampling was limited to only one accession from each locality. Consequently, we mostly focused on the genetic structure of $S$. aristata accessions rather than estimating population genetic parameters. The necessity of having a general grouping before any genetic analysis made us to divide the accessions under study into four geographical groups with no taxonomic sense (i.e. Esfahan, Qazvin, Azerbaijan and Kurdistan).

Total DNA was extracted using dried leaf material based on a modified CTAB method (Doyle and Doyle 1987). To prevent the effect of and the breaking down the secondary metabolites, CTAB and dried leaf solution was kept for 24 hours at room temperature. DNA extracts were dissolved in $70 \mu \mathrm{l}$ deionised water. A total number of 16 combinations from 6 pairs (Table 2) of SRAP primers (Li et al. 2015) were examined. PCR amplification was carried out in a volume of $25 \mu \mathrm{l}$, containing $10.5 \mu \mathrm{l}$ deionised water, $12.5 \mu \mathrm{l}$ of Taq DNA polymerase $\mathrm{r}$ master mix Red (Amplicon, Cat. no. 180301), $0.5 \mu \mathrm{l}(10 \mathrm{p} \mathrm{mol} / \mathrm{ml})$ of each of the primers and $1 \mu \mathrm{l}(50 \mathrm{ng} / \mu \mathrm{l})$ of template DNA. Polymerase chain reaction was based on (Li and Quiros 2001) as: initial denaturation at $94{ }^{\circ} \mathrm{C}$ for $4 \mathrm{~min}$ followed by five cycles including $1 \mathrm{~min}$ at $94^{\circ} \mathrm{C}$ denaturation, 1 min annealing at $35^{\circ} \mathrm{C}$ and $1 \mathrm{~min}$ of elongation at $72^{\circ} \mathrm{C}$. Following 35 cycles as: denaturation at $94^{\circ} \mathrm{C}$ for $1 \mathrm{~min}$, annealing at $55^{\circ} \mathrm{C}$ for $1 \mathrm{~min}$ and elongation at $72{ }^{\circ} \mathrm{C}$ for $1 \mathrm{~min}$ with final extension for $1 \mathrm{~min}$ at $72{ }^{\circ} \mathrm{C}$ was carried out. The PCR products were ran on an electrophoresis gel of $1.5 \%$ agarose containing ethidium bromide.

\section{Data analyses}

Eleven primer combinations of SRAP primers were selected according to their ability to produce clear and polymorphic bands among accessions (Table 3). All the clear bands were scored as 1 for presence, 0 for absence and the faint bands were treated as missing data. The polymorphic information content (PIC) was used to evaluate the ability of SRAP markers in the assessment of inter accession genetic diversity of $S$. aristata as follows:

$$
P I C=2 \sum f_{i}\left(1-f_{i}\right)
$$

where $\mathrm{f}_{\mathrm{i}}$ is the frequency of the present marker fragments (Li et al. 2015). 
Table 1

Localities of Salvia aristata specimens used for DNA extraction in this study. The letters (a $\& b$ ) are for subscript indicating the relevant groups in the STRUCTURE analysis

\begin{tabular}{|c|c|c|c|c|}
\hline \multirow{2}{*}{$\begin{array}{l}\text { Acces- } \\
\text { sions } \\
\text { no. }\end{array}$} & \multicolumn{2}{|c|}{$\begin{array}{l}\text { Geographical } \\
\text { coordinate }\end{array}$} & \multirow{2}{*}{ Origin } & \multirow{2}{*}{$\begin{array}{l}\text { Geographical re- } \\
\text { gions grouping }\end{array}$} \\
\hline & lat. & long. & & \\
\hline Sa-01 a & $33.17^{\circ}$ & $50.18^{\circ}$ & $\begin{array}{l}\text { Esfahan: Tiran to Damaneh, Tange kol- } \\
\text { ang, } 2500 \mathrm{~m}, 12495 \text { TARI }\end{array}$ & Esfahan \\
\hline $\mathrm{Sa}-02 \mathrm{a}_{\mathrm{a}}$ & $32.05^{\circ}$ & $51.47^{\circ}$ & $\begin{array}{l}\text { Esfahan: Ghameshlou, Sanjab pass } \\
\text { (Halaj), } 2230 \text { m, } 90369 \text { TARI }\end{array}$ & Esfahan \\
\hline Sa-03 a & $33.07^{\circ}$ & $50.45^{\circ}$ & $\begin{array}{l}\text { Esfahan: Khansar: Darre bid, } 2700 \text { m, } \\
13607 \text { TARI }\end{array}$ & Esfahan \\
\hline $\mathrm{Sa}-04_{\mathrm{a}}$ & $32.05^{\circ}$ & $51.47^{\circ}$ & $\begin{array}{l}\text { Esfahan: Ghameshlou protected area, } \\
2350 \mathrm{~m}, 1118 \text { TARI }\end{array}$ & Esfahan \\
\hline Sa-05a & $33.21^{\circ}$ & $50.21^{\circ}$ & $\begin{array}{l}\text { Esfahan: Faridan, Daran, Tarrar, } 2450 \text { m, } \\
13266 \text { TARI }\end{array}$ & Esfahan \\
\hline $\mathrm{Sa}-06_{\mathrm{a}}$ & $32.05^{\circ}$ & $51.47^{\circ}$ & $\begin{array}{l}\text { Esfahan: Ghameshlou, Sanjab, } 2200 \text { m, } \\
90328 \text { TARI }\end{array}$ & Esfahan \\
\hline Sa-07 a & $32.05^{\circ}$ & $51.47^{\circ}$ & $\begin{array}{l}\text { Esfahan: Ghameshlou, protected area, } \\
\text { Tange darposht, } 2200 \text { m, } 1203 \text { TARI }\end{array}$ & Esfahan \\
\hline $\mathrm{Sa}-08_{\mathrm{a}}$ & $32.89^{\circ}$ & $50.07^{\circ}$ & $\begin{array}{l}\text { Esfahan: Fereydunshahr, near the vil- } \\
\text { lage Sibak, } 2900 \text { m, } 76486 \text { TARI }\end{array}$ & Esfahan \\
\hline Sa-09a & $32.89^{\circ}$ & $50.07^{\circ}$ & $\begin{array}{l}\text { Esfahan: Fereydunshahr, Sibak, } 2670 \text { m, } \\
90331 \text { TARI }\end{array}$ & Esfahan \\
\hline Sa-10 a & $32.05^{\circ}$ & $51.47^{\circ}$ & $\begin{array}{l}\text { Esfahan: Ghameshlou, Sanjab, } 90336 \\
\text { TARI }\end{array}$ & Esfahan \\
\hline Sa-11 & $32.05^{\circ}$ & $51.47^{\circ}$ & $\begin{array}{l}\text { Esfahan: Ghameshlou, Gardaneh ka- } \\
\text { hurak }\end{array}$ & Esfahan \\
\hline Sa-12 a & $32.94^{\circ}$ & $50.09^{\circ}$ & $\begin{array}{l}\text { Esfahan: Fereydunshahr, 12691/23, } 2500 \\
\text { m TARI }\end{array}$ & Esfahan \\
\hline $\mathrm{Sa}_{13}$ & $33.42^{\circ}$ & $49.29^{\circ}$ & $\begin{array}{l}\text { Lorestan, Oshtorankuh, above Tihun } \\
\text { village, 37072/24, 2000-2500 m TARI }\end{array}$ & Esfahan \\
\hline Sa-14 a & $35.57^{\circ}$ & $49.21^{\circ}$ & $\begin{array}{l}\text { Ghazvin to Hamedan just after Avaj, } \\
2100 \text { m, } 36689 \text { TARI }\end{array}$ & Ghazvin \\
\hline Sa- $15_{b}$ & $36.42^{\circ}$ & $50.03^{\circ}$ & $\begin{array}{l}\text { Ghazvin: Aloak to Esbzad, } 2120 \text { m, } \\
90329 \text { TARI }\end{array}$ & Ghazvin \\
\hline Sa-16a & $34.89^{\circ}$ & $49.26^{\circ}$ & $\begin{array}{l}\text { Arak: Komayjan, Pass of Chehregan vil- } \\
\text { lage, the margin road, } 2350 \text { m, } 501 \text { TARI }\end{array}$ & Ghazvin \\
\hline Sa- $17_{b}$ & $37.35^{\circ}$ & $45.15^{\circ}$ & Azerbaijan: Darre Ghameshlou & Azerbaijan \\
\hline Sa- $18_{b}$ & $37.68^{\circ}$ & $48.47^{\circ}$ & $\begin{array}{l}\text { Azerbaijan: } 78 \mathrm{~km} \text { from Mianeh to } \\
\text { Khalkhal, } 1500 \mathrm{~m}, 56889 \text { TARI }\end{array}$ & Azerbaijan \\
\hline
\end{tabular}


Table 1 (continued)

\begin{tabular}{|c|c|c|c|c|}
\hline \multirow{2}{*}{$\begin{array}{l}\text { Acces- } \\
\text { sions } \\
\text { no. }\end{array}$} & \multicolumn{2}{|c|}{$\begin{array}{l}\text { Geographical } \\
\text { coordinate }\end{array}$} & \multirow[t]{2}{*}{ Origin } & \multirow{2}{*}{$\begin{array}{l}\text { Geographical re- } \\
\text { gions grouping }\end{array}$} \\
\hline & lat. & long. & & \\
\hline Sa-19 & $38.37^{\circ}$ & $45.47^{\circ}$ & $\begin{array}{l}\text { Azerbaijan: from Tabriz to Marand after } \\
\text { Soufian, } 1500 \mathrm{~m}\end{array}$ & Azerbaijan \\
\hline Sa- $20_{b}$ & $37.59^{\circ}$ & $48.22^{\circ}$ & $\begin{array}{l}\text { Azerbaijan: } 35 \text { km from Kivi, Firou- } \\
\text { zabad, 1180-1350 m, } 34230 \text { TARI }\end{array}$ & Azerbaijan \\
\hline Sa- $21_{b}$ & $37.67^{\circ}$ & $48.47^{\circ}$ & $\begin{array}{l}\text { Azerbaijan: } 14 \mathrm{~km} \text { from Khalkhal to } \\
\text { Kivi, Anavis, village, } 1680 \mathrm{~m}, 34149 \\
\text { TARI. }\end{array}$ & Azerbaijan \\
\hline Sa- $22_{b}$ & $37.35^{\circ}$ & $45.15^{\circ}$ & Azerbaijan: Darreh Ghasemlou & Azerbaijan \\
\hline Sa-23 & $35.14^{\circ}$ & $47.10^{\circ}$ & $\begin{array}{l}\text { Kurdistan: Sanandaj, Narran village, } \\
1850 \text { m, } 72\end{array}$ & Kurdistan \\
\hline Sa-24 & $35.14^{\circ}$ & $47.10^{\circ}$ & $\begin{array}{l}\text { Kurdistan: } 25 \text { km from Sanandaj, moun- } \\
\text { tain above Narran village, 1850-2600 m, } \\
60235 \text { (TARI). }\end{array}$ & Kurdistan \\
\hline Sa-25 & $36.38^{\circ}$ & $46.04^{\circ}$ & $\begin{array}{l}\text { Kurdistan: Saghez, Zanbill village, } \\
\text { 1300-1360 m, } 5103 \text { (TARI). }\end{array}$ & Kurdistan \\
\hline
\end{tabular}

Genetic relationships and structure

To estimate the genetic distance among $S$. aristata specimens, we calculated Euclidean genetic distance applying agglomerative (hierarchical) clustering using Ward's variance minimisation algorithm implemented in scipy python package. In addition, a model based computation using Bayesian method implemented in SRUCTURE software (Pritchard et al. 2000) was performed. For input data, all samples are grouped into four geographical regions (Table 1) as a priori grouping knowledge for STRUCTURE analysis. The analysis was done under admixture ancestor and correlated allele frequency model. In each run

Table 2

Forwarded and reversed primers sequences using in this study for SRAP marker

\begin{tabular}{cccc}
\hline & \multicolumn{2}{c}{ Forwarded primers } & \multicolumn{2}{c}{ Reversed primers } \\
\hline Me2 & 5'-TGAGTCCAAACCGGAGC-3' $^{\prime}$ & Em1 & 5'-GACTGCGTACGAATTAAT-3' \\
Me5 & 5'-TGAGTCCAAACCGGAAG-3' $^{\prime}$ & Em2 & 5'-GACTGCGTACGAATTTGC-3' \\
Me1 & 5'-TGAGTCCAAACCGGAAT-3' & Em3 & 5'-GACTGCGTACGAATTGAC-3' \\
Me3 & $5^{\prime}$ 'TGAGTCCAAACCGGACC-3' & Em4 & 5'-GACTGCGTACGAATTTGA-3' \\
Me4 & 5'-TGAGTCCAAACCGGACC-3' & Em6 & 5'-GACTGCGTACGAATTGCA-3' \\
Me2 & 5'-TGAGTCCAAACCGGAGC-3' & Em17 & 5'-GACTGCGTACGAATTCCA-3' \\
\hline
\end{tabular}


50,000 Markov Chain Monte Carlo was simulated with 5000 burn in. Number of groups $(\mathrm{K})$ was assumed from 1 to 8 and 20 independent runs were performed for each $\mathrm{K}$ value. The output of structure was analysed by Harvester (Earl and vonHoldt 2012). To determine the number of real clusters (K), per the $\triangle K$ CLUMPP software (Jakobsson and Rosenberg 2007) was used to find out the optimum alignment of replication in clustering analysis by STRUCTURE result. The output was visualised by Distruct (Rosenberg 2004).

\section{Ecological niche modelling}

Ecological niche modelling was applied to evaluate the degree of ecological divergence between the genetic clusters generated in S. aristata where $\mathrm{K}=2$. All 25 accessions were assigned to putative lineages in group A (mostly central area of Iran) and group B (mostly western and northwestern area of Iran). Since group B had one genealogical clustering in STRUCTURE analyses, to provide additional points 11 more records (Hedge 1982) from northwestern part of Iran were georeferenced and were assigned to group B. Furthermore, due to the similarity between the climate conditions of the locality of $S$. aristata in Turkey (Van: Baskale district) with that of the area around Iranian Urmia Lake in northwestern (Tali et al. 2013), the recent report of this species from Turkey (Behçet and Avlamaz 2009) was assigned to the putative lineage of group B. We used 14 occurrence points for group A and 23 occurrence point for group B.

A total of 19 bioclimatic variables along with altitude were downloaded from WorldClim database V. 1.4 and 2 (http://www.worldclim.org, Hijmans et al. 2005, Fick and Hijmans 2017). We performed ecological niche modelling to predict the potential distribution of S. aristata at present (1970-2000) and the last glacial maximum (LGM; $22 \mathrm{Kya}$ ). For bioclimatic along with altitudinal layers, 2.5 arc-minute resolution was used for both building the model and projection into the present and LGM. Bioclim variables were extracted and cropped to the extent of Iran and Turkey (which contain all known occurrences for S. aristata). To avoid model over-fit, we reduced variables for modelling by taking only one variable for each pairwise comparison where the Pearson's correlation was at least 0.8. Seven Bioclim layers along with altitude were retained for modelling: Bio3 (isothermality), Bio4 (temperature seasonality), Bio7 (temperature annual range), Bio8 (mean temperature of wettest quarter), Bio12 (annual precipitation), and Bio18 (precipitation of warmest quarter). All analyses were carried out in R (R CoreTeam 2015) using the packages raster (Hijmans and Van Etten 2012) and rgdal (Bivand et al. 2014).

We generated ENMs for putative taxa in S. aristata using the maximum entropy algorithm implemented in Maxent v.3.3 (Phillips et al. 2006). Previous studies showed that Maxent performs well in comparison to other methods for relatively small occurrence record sample sizes (Baldwin 2009, Vroh et al. 
2016), an important property for modelling narrow endemics. To generate models, we used $75 \%$ of occurrence point for testing and $25 \%$ for training with 5,000 iterations. The number of background points was set to 10,000. The convergence threshold of 0.00001 was applied and the output format was set to be logistic. Cross-validation replicated runs were used due to better performance for small data in comparison with bootstrap and sub-sampling methods (Phillips et al. 2006). To evaluate the model, the area under the receiver operating characteristic (ROC) curve (AUC) was estimated. AUC measures the ability of a model to discriminate between the present size and absent size by taking the random sample from the population (Phillips et al. 2006). We performed a Jack-knife test to assess the importance of each environmental variable in our modelling. The output models of Maxent were created using QGIS 2.18.0 (QGIS 2015). To evaluate the niche overlap among group A and group B of $S$. aristata, we used Schoener's D (Schoener and Schoener 2015) and Hellinger'sbased I (Warren et al. 2008) in R (R Core Team 2015) using package ENMTools 1.4.4 (Warren et al. 2010). Both $D$ and I range between 0 (complete lack of niche overlap) and 1 (identical niches). Niche identity tests were performed with 100 replicates to determine whether any observed niche differences between the two putative ecotypes of $S$. aristata were significant, under a null hypothesis assuming no niche differentiation among putative species. In addition, we ran background test with 100 pseudo-replicates to evaluate whether ENMs were more similar than expected by chance, in case that species or individuals choose a random point from their geographic area.

\section{RESULTS}

\section{Molecular observations}

Using 11/16 SRAP primer combinations a total of 242 scorable bands ranging in size from 120 to $1700 \mathrm{bp}$ were produced. Our results showed that $98.33 \%$ of the amplified loci were polymorphic. The minimum (16) and maximum (27) bands were scored for Me2-Em1 and Me3-Em1, respectively (Table 3). The polymorphic information content (PIC) values ranged from 0.39 to 0.49 with an average of 0.42 . The highest and lowest PIC values were obtained for Me4Me2 and Me5Me4 combinations, respectively. The higher PIC is an indicator of the ability of primer combination to detect the allelic polymorphisms.

\section{Genetic relationships and structure results}

Genetic distance results showed that our accessions are grouped into two main clusters with two and three sub-clusters in each (Fig. 1). Cluster I comprises most of Esfahan's accessions along with two individuals from Kurd- 
Table 3

Total number of produced band, polymorphic bands, polymorphism percentage and polymorphic information criterion (PIC) obtained from 11 SRAP primer combinations

\begin{tabular}{lcccc}
\hline $\begin{array}{l}\text { Primer } \\
\text { combination }\end{array}$ & $\begin{array}{c}\text { Produced } \\
\text { band }\end{array}$ & $\begin{array}{c}\text { Polymorphic } \\
\text { band }\end{array}$ & $\begin{array}{c}\text { Polymor- } \\
\text { phism\% }\end{array}$ & PIC \\
\hline Me3em3 & 18 & 17 & 94.4 & 0.46 \\
Me3em1 & 24 & 24 & 100 & 0.47 \\
Me5em6 & 19 & 18 & 94.7 & 0.40 \\
Me4em2 & 22 & 22 & 100 & 0.49 \\
Me3em2 & 20 & 19 & 95 & 0.29 \\
Me4em1 & 19 & 19 & 100 & 0.40 \\
Me3em4 & 24 & 21 & 87.5 & 0.39 \\
Me2em17 & 17 & 16 & 94 & 0.46 \\
Me1em2 & 26 & 26 & 100 & 0.46 \\
Me5em1 & 26 & 26 & 100 & 0.36 \\
Me4em3 & 27 & 27 & 100 & 0.47 \\
\hline Total/Average & T: 242 & T: 235 & AVG: 96.87 & AVG: 0.42 \\
\hline
\end{tabular}

istan (Sa-24 and Sa-23) and two individuals from Qazvin (Sa-14 and Sa-16). Cluster II includes most of Azerbaijan's populations with one individual from Qazvin (Sa-15). STRUCTURE analysis revealed that the $\Delta K$ (Fig. 2) reaches the greatest value when the $\mathrm{K}=2$; it implies that $S$. aristata accessions are assigned to two different genetic ecotypes (groups A and B illustrated in Fig. 3).

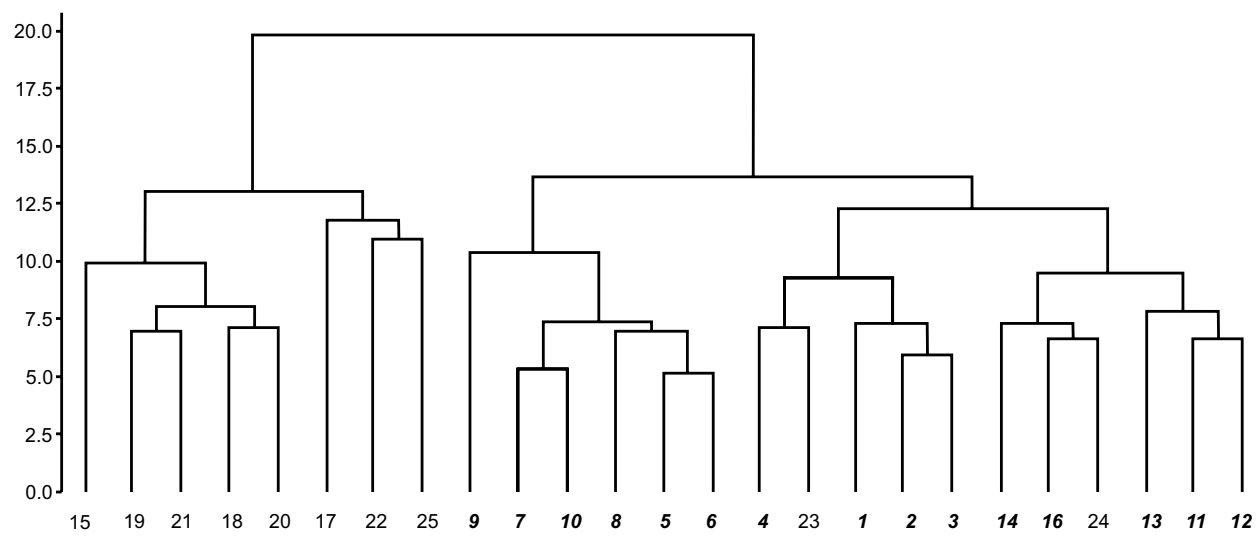

Fig. 1. The dendrogram is based on the genetic distance of $S$. aristata accessions using 11 primer combinations of SRAP marker. The bold italic locality numbers show the clusters of Groups A, regular locality numbers stand for the clusters of Groups B (in accordance with structure analysis) 
Table 4

Level contribution of each bioclim variable in present niche model generated by Maxent for group A and group B based on Jacknife test

\begin{tabular}{llcc}
\hline & Description of variable & Group A\% & Group B\% \\
\hline Bio3 & Isothermality & 13.3 & 16.7 \\
Bio4 & Temperature seasonality & 0.3 & 5.8 \\
Bio7 & Temperature annual range & 14.5 & 0.5 \\
Bio8 & Mean temperature of wettest quarter & 56.7 & 1.3 \\
Bio12 & Annual precipitation & 3.4 & 32.3 \\
Bio18 & Precipitation of warmest quarter test & 13.3 & 11.7 \\
\hline
\end{tabular}

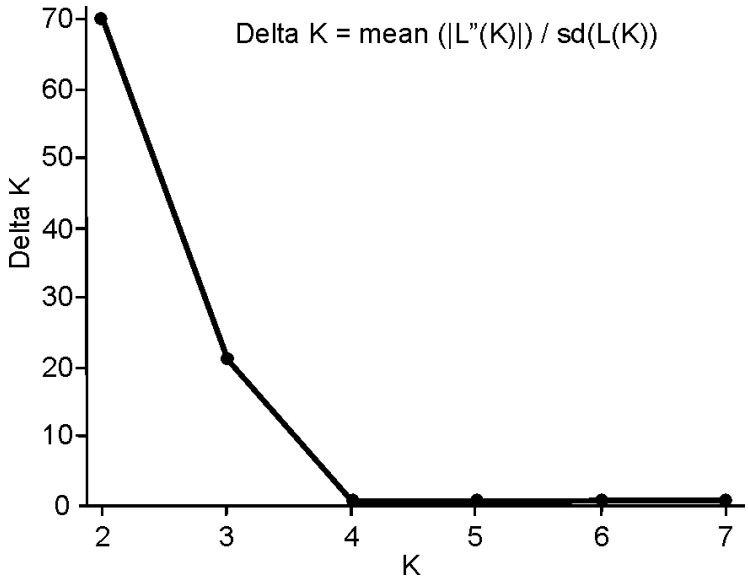

Fig. 2. The correlation of $\mathrm{K}$ and $\Delta \mathrm{K}$ obtained from Harvester analysis to determine the best $\mathrm{K}$ of structure analysis

\section{Ecological niche modelling}

The predicted distribution of the two ecotypes at present, during LGM (last glacial maximum) is shown in Figures 4 and 5, respectively. The AUC scores for group A was 0.94 and for group B was 0.96. The AUC scores showed that the model has a good fit for individuals. Our model predicted a patchily potential suitable area for $S$. aristata accessions. The results suggested that Kopet Dagh Mts and a narrow part

Group B

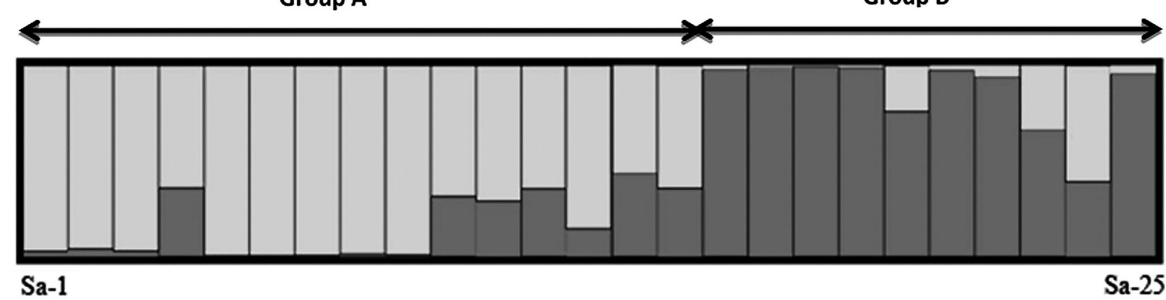

Fig. 3. STRUCTURE analysis showing delimitation of $S$. aristata accessions into two ecotypes. Vertical lines shows individuals within ecotypes. From left to right individuals are arranged from Sa-1 to Sa-25 (for details see Table 1) 

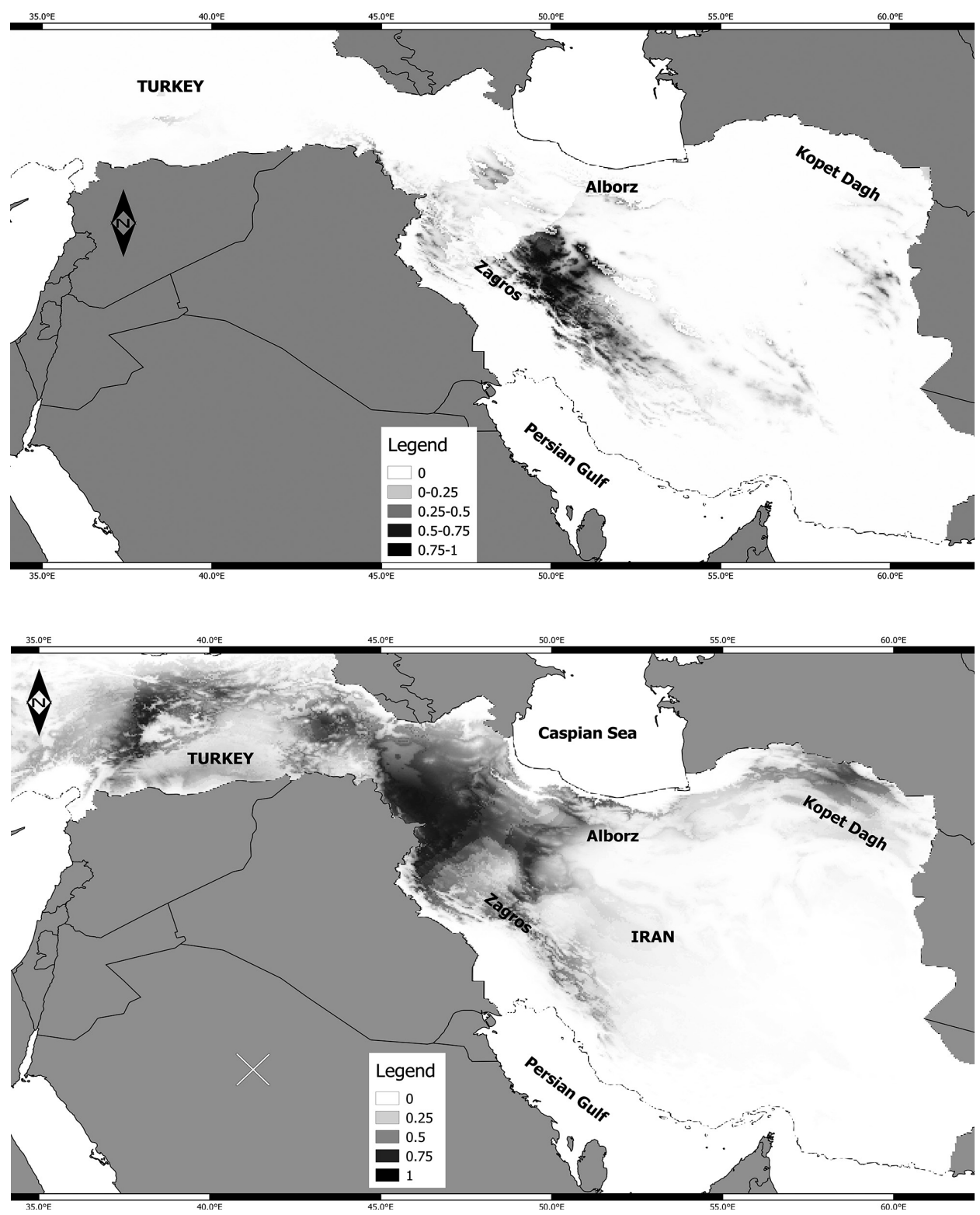

Fig. 4. Potential current of occurrence for S. aristata in Group A (top) and Group B (bottom) generated by Maxent. Rang of suitable areas are shown in colour. Higher value indicates of more suitable area for $S$. aristata 
of Alborz Mountains in Northeast of Iran are potentially suitable areas for $S$. aristata occurrence (Fig. 4). Although no S. aristata specimen is recorded from Kopet Dagh Mts so far, this area is potentially suitable habitat for occurrence
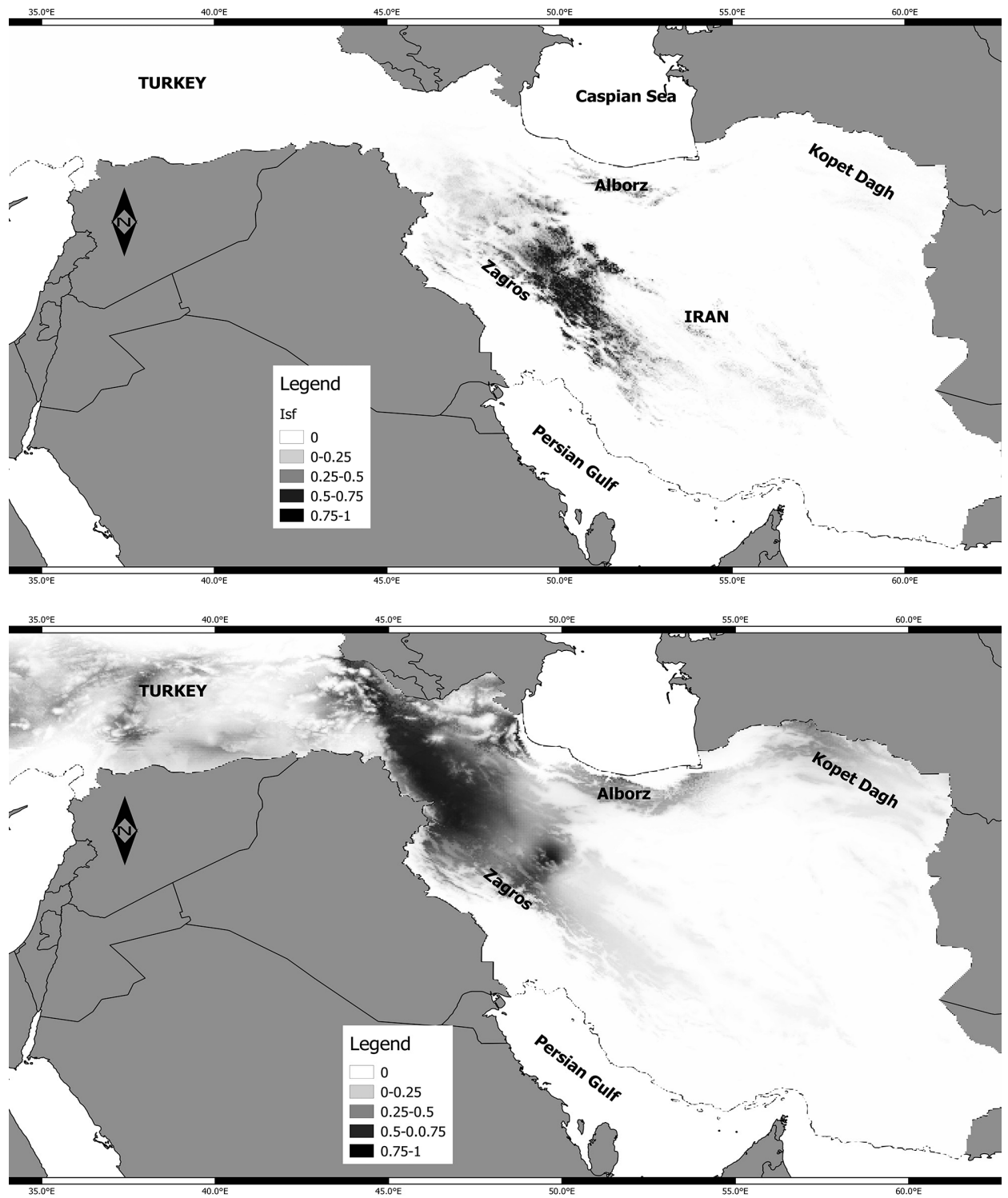

Fig. 5. Past distribution (last glacial maximum $\sim 22 \mathrm{kya}$ ) of occurrence for S. aristata in Group A (top) and Group B (bottom) generated by Maxent. Rang of suitable areas are shown in colour. Higher value indicates of more suitable area for $S$. aristata 
of this species based on niche model generated by Maxent for group A. The Jack-knife test of Maxent analysis showed that altitude and mean temperature of the wettest quarter are the two highly contributing variables for group A. In addition, altitude and annual precipitation are the most contributing factors in niche model for group B (Table 4). While Schoner's D and Hellinger's-based I can range from 0 (no niche overlap) to 1 (identical niches), the estimated niche overlap of the groups A and B produced Schoner's D $=0.21$ and Hellinger'sbased I $=0.44$ (Fig. 6). Niche identity test showed that the observed value for $\mathrm{D}$ and I are significant because the observed overlap falls outside of 95 percent confidence. Therefore, the null hypothesis of similar niches was rejected and different niches for group A and group B are accepted (Fig. 6A). The domain background test (Fig. 6B) with 100 pseudo-replicates rejected the null hypothesis of similar niches as well. We also estimated the raster niche overlap of last glacial maximum to be 0.53 , which shows greater than the present raster overlap to be 0.44 . Higher niche overlap indicates no functional barrier of gene flow between two ecotypes in the past.

\section{DISCUSSION}

\section{Genetic variability}

In accordance with the recent studies (Robarts and Wolfe 2014, Talebi et al. 2015), our results showed that SRAP marker is a robust tool to show genetic variations among accessions so that $97.11 \%$ of the loci were polymorphic. PIC (polymorphic information content), which refers to the value of a marker for

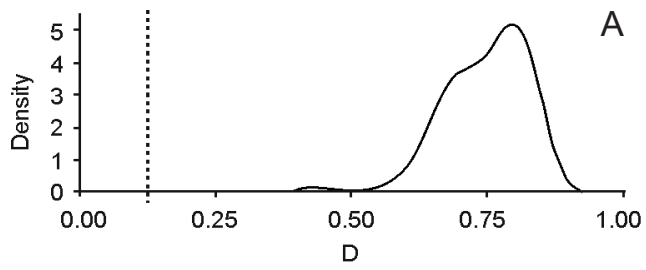

A

B
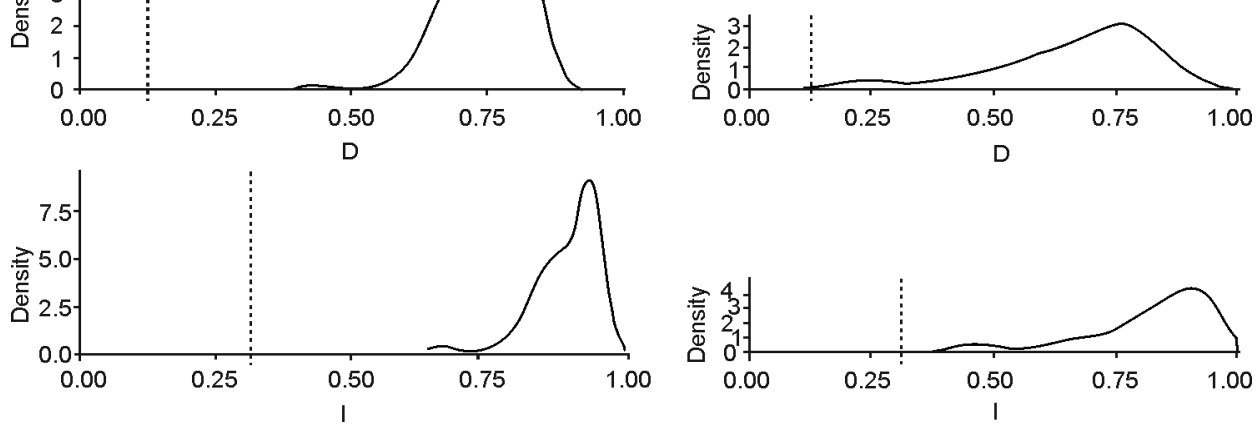

Fig. 6. Niche overlap value D (Schoener's) and I (Hellinger's-based). Left: Niche identity test. Right: Background similarity test. The $X$ axis shows the value of $\mathrm{D}$ and $\mathrm{I}$ and the $\mathrm{Y}$ axis indicates number of pseudo-replicates. The dotted lines are the observed overlap for real data. The observed overlap falls outside the 95\% CI null distribution that means the null hypothesis of similar niches are rejected 
detecting polymorphism could be classified into three groups. In the case of PIC $>0.5,0.25<$ PIC $<0.5$ and PIC $<0.25$ the value for that marker is high, medium and low, respectively (Liu and Cordes 2004). Eleven primer combinations of SRAP marker (Table 2) used in the present study having an average of PIC $=0.42$ showed that SRAP marker could provide useful data to assess genetic variation in S. aristata accessions. Here, Me4em2 with a PIC of 0.49 among the others was the most informative primer combination.

\section{Species delimitation and mode of speciation}

Based on the genetic distance dendrogram illustrated in Figure 2, S. aristata accessions are grouped into two main clusters (groups A and B) with three and two subclusters in each, respectively. The above grouping is also consistent with the structure clustering by detecting two main putative genetic lineages (Fig. 3). Reeves and Richards (2011) pointed out that in the case of incomplete sampling, evidence in favour of niche divergence or reproductive isolation is essential rather than just focusing on genetic data. To make conclusion about the population's behaviour in S. aristata and due to our insufficient sampling, we used ecological niche modelling method to examine niche divergence between these two ecotypes as well.

Nosil and Sandoval (2008) reported the role of niche divergence in stick insects (Timema) as a key factor in ecological speciation process through local adaptation even in the presence of gene flow. Elias et al. (2012), Khimoun et al. (2013) and Nosil et al. (2009), also expressed that ecological divergence and its contributing role in speciation is more prominent when characters related to gene flow such as pollinators, phenological properties and reproductive characters are diverged among populations. The results of structure clustering (Fig. 3) are consistent with the variation encountered in some phenotypic floral traits. The accessions Sa-15, Sa-18, Sa-19, Sa-20 and Sa-21, belonging to group $B$ (lacking the middle tooth in the upper lip of the calyx) form a distinct ecotype, while the remaining having the middle tooth stand as a different ecotype. However, those with a mix genetic composition of both ecotypes (Fig. 3) showed middle tooth in the same length or smaller than the two ecotypes. The consistency between the phenotypic variability and the clusters of structure analysis can be taken as evidence to confirm a current divergence between the two ecotypes.

As a general rule, insects are the pollinators of Salvia in Old World (ClaBen-Bockhoff et al. 2004). At the lower elevations, bees and at the higher altitudes insects like flies are the dominate pollinators among bilabiate flowers such as Salvia (Pellissier et al. 2010). Based on the Maxent results of this study, altitude appeared as an important factor contributing to the niche model of 
groups $\mathrm{A}$ and $\mathrm{B}$, while all the accessions belonging to group $\mathrm{A}$ are occurring at the altitudes between 2000 to $2900 \mathrm{~m}$, the accessions of group B are growing from 1180 to $2100 \mathrm{~m}$. Therefore, it can be inferred that phenotypic variants of the calyx teeth could be considered as a pollinator-mediated adaptive divergence. To conclude, if we assume that this pattern of phenotypic divergence is somehow directed by both quantity and quality of the pollinators involved, it can be suggested that $S$. aristata is at a degree of speciation; providing the presence of a progressing divergence accompanied with the reproductive isolation, the originating of varieties, subspecies and new species can be expected.

Although the general evolutionary mechanism of all species passes through the origin, expansion and demise, however each of them has their own exclusive pathway (Levin 2000). Traditionally, the mode of specifications is classified into three categories: sympatric, allopatric and parapatric (Coyne and Orr 1998, Lowe et al. 2004). Allopatric mode depends on the geographical barriers and lack of gene flow. Sympatric (complete area overlap) and parapatric modes (partial area overlap) with no extrinsic barrier are controlled by the intrinsic genomic barriers (e.g. polyploidy and hybridisation) and show a decreasing gene flow as function of progressing speciation (Butlin et al. 2008, Feder et al. 2012, Zheng et al. 2017). The genetic structure of SRAP marker showed that despite the presence of a limited gene flow, two distinct ecotypes were formed which may be the consequences of reproductive isolation caused by altitude gradient and different niches through parapatric speciation.

In addition, the results of ecological niche modelling (Figs 4 and 5) showed that the niche overlap of the two ecotypes in last glacial maximum model was higher than the present model. It can be taken as evidence for the absence of a geographical barrier for conducting an allopatric speciation between these two ecotypes in the past (Fig. 5).

Based on the all ecological and genetic line evidence generated in this study, it can be suggested that the parapatric mode is the most likely mechanism involved in S. aristata speciation.

\section{CONCLUSIONS}

Based on the genetic data and niche model results of this study it can concluded that the endemic gene pool of $S$. aristata is currently undergoing a dynamic speciation process in which central (group A) and northwestern (group B) accessions are diverging from each other. The distribution of morphological traits (absence/presence of middle calyx teeth) among the accessions revealed two distinct ecotypes and a mixture of phenotypic and genetic individuals. Although some individuals by presence or absence of middle calyx tooth formed distinctive ecotypes, still some individuals showed an in- 
termediate phenotype by presence of gene flow and traits with each of the two ecotypes. In the case of selection on reproductive system supported by ecological factors, complete divergence of individuals can be predicted. In term of taxonomic conclusion, we need to consider both the morphological variability and nomenclature problems in this species. But before arranging a taxonomic revision for $S$. aristata, we prefer to examine other relevant molecular markers and data. In this respect, collecting materials from the type localities of other closely related species to $S$. aristata (mostly known as synonyms) is essential to provide enough informative molecular data to solve the taxonomic confusions.

Acknowledgements - We are grateful to the staff of TARI Herbarium for their help and cooperation. Also, we would like to thank Dr Dan Warren for his helpful comments on niche modelling and niche overlap results. We also thank Dr Ryan Folk for reviewing part of the manuscript. This study was carried out by the financial support of the University of Isfahan.

\section{REFERENCES}

Alvarado-Serrano, D. F. and Knowles, K. (2014): Ecological niche models in phylogeographic studies: applications, advances and precautions. - Mol. Ecol. Res. 14: 233-248. https://doi.org/10.1111/1755-0998.12184

Anacker, B. L. and Strauss, S. Y. (2014): The geography and ecology of plant speciation: range overlap and niche divergence in sister species. - Proc. R. Soc. B Biol. Sci. 281(1778): 20132980. https://doi.org/10.1098/rspb.2013.2980

Baldwin, R. A. (2009): Use of maximum entropy modeling in wildlife research. - Entropy 11(4): 854-866. https://doi.org/10.3390/e11040854

Behçet, L. and Avlamaz, D. (2009): A new record for Turkey: Salvia aristata Aucher ex Benth. (Lamiaceae). - Turk. J. Bot. 33(1): 61-63. https://doi.org/10.3906/bot-0808-14

Bentham, G. (1848): Labiatae. - In: de Candolle, A. (ed.): Prodromus. Vol. 12. 1st ed. Paris, France: Treuttel and Würtz, pp. 262-358.

Bivand, R., Keitt, T. and Rowlingson, B. (2014): Rgdal: bindings for the geospatial data abstraction library. R Package Version 0.9-1. - http://CRAN.R-project.org/package=rgdal.

Busby, J. R. (1991): A bioclimatic analysis and prediction system. - In: Margules, C. R. and Austin, M. P. (eds): Nature conservation: cost effective biological surveys and data analysis. CSIRO, Sydney, New South Wales, pp. 64-68.

Butlin, R. K., Galindo, J., Grahame, J. W. and Sheffield, S. (2008): Sympatric, parapatric or allopatric: the most important way to classify speciation? - Trans. R. Soc. Land. B. 363 : 2997-3007. https://doi.org/10.1098/rstb.2008.0076

Chang, D., Yang, F. Y., Yan, J. J., Wu, Y. Q., Bai, S. Q., Liang, X. Z. and Gan, Y. M. (2012): SRAP analysis of genetic diversity of nine native populations of wild sugarcane, Saccharum spontaneum, from Sichuan, China. - Genet. Mol. Res. 11(2): 1245-1253. https://doi.org/10.4238/2012.May.9.3 \rgmr1521 [pii] 
Claßen-Bockhoff, R., Speck, T., Tweraser, E., Wester, P., Thimm, S. and Reith, M. (2004): The staminal lever mechanism in Salvia L. (Lamiaceae): a key innovation for adaptive radiation? - Org. Divers. Evol. 4(3): 189-205. https://doi.org/10.1016/j.ode.2004.01.004

Coyne, J. A. and Orr, H. A. (1998): The evolutionary genetics of speciation. - Phil. Trans. R. Soc. Land. B. 353: 287-305.

De Queiroz, K. (2007): Species concepts and species delimitation. - Syst. Biol. 56(6): 879886. https://doi.org/10.1080/10635150701701083

DeSalle, R., Egan, M. G. and Siddall, M. (2005): The unholy trinity: taxonomy, species delimitation and DNA barcoding. - Philos. Trans. R. Soc. B Biol. Sci. 360(1462): 19051916. https://doi.org/10.1098/rstb.2005.1722

Doyle, J. J. and Doyle, J. L. (1987): A rapid isolation procedure for small quantities of fresh leaf tissue. - Phytochem. Bull. 19: 11-15.

Earl, D. A. and vonHoldt, B. M. (2012): STRUCTURE HARVESTER: A website and program for visualizing STRUCTURE output and implementing the Evanno method. - Conserv. Genet. Resour. 4(2): 359-361. https://doi.org/10.1007/s12686-011-9548-7

Elias, M., Faria, R., Gompert, Z. \& Hendry, A. (2012): Factors influencing progress toward ecological speciation. -Int. J. Evol. Biol.2012(i):1-7.https://doi.org/10.1155/2012/235010

Erbano, M., Schnell e Schühli, G. and Pereira dos Santos, É. (2015): Genetic variability and population structure of Salvia lachnostachys: implications for breeding and conservation programs. - Int. J. Mol. Sci. 16(4): 7839-7850. https://doi.org/10.3390 /ijms16047839

Feder, J. L., Egan, S. P. and Nosil, P. (2012): The genomics of speciation-with-gene-flow. Trends Genet. 28(7): 342-350. https://doi.org/10.1016/j.tig.2012.03.009

Fick, S. E. and Hijmans, R. J. (2017): Worldclim 2: new 1-km spatial resolution climate surfaces for global land areas. - Int. J. Climatol. 37(12): 4302-4315. https://doi.org/10 $.1002 /$ joc.5086

Fujita, M. K., Leaché, A. D., Burbrink, F. T., McGuire, J. A. and Moritz, C. (2012): Coalescent-based species delimitation in an integrative taxonomy. - Trends Ecol. Evol. 27(9): 480-488. https://doi.org/10.1016/j.tree.2012.04.012

Guisan, A. and Thuiller, W. (2005): Predicting species distribution: offering more than simple habitat models. - Ecol. Lett. 8: 993-1009. https://doi.org/10.1111/j.1461-0248.2005 .00792.x

Hedge, I. C. (1982): Salvia L. - In Rechinger, K. H. (ed.): Red data book of Iran. Flora Iranica 150.

Hijmans, R. J. and Van Etten, J. (2012): Geographic analysis and modeling with raster data. http://raster.r-forge.r-project.org/

Hijmans, R. J., Cameron, S. E., Parra, J. L., Jones, P. G. and Jarvis, A. (2005): Very high resolution interpolated climate surfaces for global land areas. - Int. J. Climatol. 25(15): 1965-1978. https://doi.org/10.1002/joc.1276

Jakobsson, M. and Rosenberg, N. A. (2007): CLUMPP: a cluster matching and permutation program for dealing with label switching and multimodality in analysis of population structure. - Bioinformatics 23(14): 1801-1806. https://doi.org/10.1093 /bioinformatics/btm233

Jamzad, Z. (2012): Lamiaceae. - In: Assadi, M., Maassoumi, A. and Mozaffarian, V. (eds): Flora of Iran. Vol. 76. Research Institute of Forests and Rangelands, Tehran, 810 pp.

Khimoun, A., Cornuault, J., Burrus, M., Pujol, B., Thebaud, C. and Andalo, C. (2013): Ecology predicts parapatric distributions in two closely related Antirrhinum majus subspecies. - Evol. Ecol. 27(1): 51-64. https://doi.org/10.1007/s10682-012-9574-2 
Knowles, L. L., Carstens, B. C. and Keat, M. L. (2007): Report coupling genetic and ecological-niche models to examine how past population distributions contribute to divergence. - Curr. Biol. 17: 940-946. https://doi.org/10.1016/j.cub.2007.04.033

Kozak, K. H., Graham, C. H. and Wiens, J. J. (2008): Integrating GIS-based environmental data into evolutionary biology. - Trends Ecol. Evol. 23(3): 141-148. https://doi.org/10 .1016/j.tree.2008.02.001

Levin, D. A. (2000): The origin, expansion, and demise of plant species. - Oxford University Press, Oxford, pp. 6-59.

Li, G. and Quiros, C. F. (2001): Sequence-related amplified polymorphism (SRAP), a new marker system based on a simple PCR reaction: Its application to mapping and gene tagging in Brassica. - Trends Ecol. Evol. 103(2-3): 455-461. https://doi.org/10.1007 /s001220100570

Li, P., Zhan, X., Que, Q., Qu, W., Liu, M., Ouyang, K. and Chen, X. (2015): Genetic diversity and population structure of Toona ciliata Roem. based on sequence-related amplified polymorphism (SRAP) markers. - Forests 6(4): 1094-1106. https://doi.org/10.3390 /f6041094

Liu, Z. J. and Cordes, J. F. (2004): Erratum to “DNA marker technologies and their applications in aquaculture genetics" [Aquaculture 238 (2004) 1-37]. - Aquaculture 242(1-4): 735-736. https://doi.org/10.1016/j.aquaculture.2004.08.022

Lowe, A., Harris, S. and Ashton, P. (2004): Ecological genetics design, analysis, and application. - Blackwell Publishing, UK, 196 pp.

Marchant, D. B., Soltis, D. E. and Soltis, P. S. (2016): Patterns of abiotic niche shifts in allopolyploids relative to their progenitors. - New Phytol. 212: 708-718. https://doi.org /10.1111/nph.14069

Nguyen H. T. and Wu, X. (2005): Molecular marker systems for genetic mapping. - In: Meksemand, K. and Kahl, G. (eds): The handbook of plant genome mapping. Wiley-Blackwell, pp. 23-50.

Nosil, P. and Sandoval, C. P. (2008): Ecological niche dimensionality and the evolutionary diversification of stick insects. - Plos One 3(4): 1-11. https://doi.org/10.1371/journal .pone.0001907

Nosil, P., Harmon, L. J. \& Seehausen, O. (2009): Ecological explanations for (incomplete) speciation. - Trends Ecol. Evol. 24(3): 145-156. https://doi.org/10.1016/j.tree.2008.10.011

Pellissier, L., Pottier, J., Vittoz, P., Dubuis, A. and Guisan, A. (2010): Spatial pattern of floral morphology: possible insight into the effects of pollinators on plant distributions. Oikos 119(11): 1805-1813. https://doi.org/10.1111/j.1600-0706.2010.18560.x

Pelletier, T. A. R. A. A. P., Risafulli, C. H. C., Agner, S. T. W., Ellmer, A. M. J. Z. and Arstens, B. R. C. C. (2015): Historical species distribution models predict species limits in western Plethodon salamanders. - Syst. Biol. 64(6): 909-925. https://doi.org/10.1093 /sysbio/syu090

Penner, G. A., Bush, A., Wise, R., Kim, W., Domier, L., Kasha, K. and Fedak, G. (1993): Reproducibility of random amplified polymorphic DNA (RAPD) analysis among laboratories. - PCR Methods Appl. 2(4): 341-345. https://doi.org/10.1101/gr.2.4.341

Phillips, S. J., Anderson, R. P. and Schapire, R. E. (2006): Maximum entropy modeling of species geographic distributions. - Ecol. Modell. 190: 231-259. https://doi.org/10.1016 /j.ecolmodel.2005.03.026

Pritchard, J. K., Stephens, M. and Donnelly, P. (2000): Inference of population structure using multilocus genotype data. - Genetics 155(2): 945-959. https://doi.org/10.1111 /j.1471-8286.2007.01758.x 
QGIS Development Team (2015): QGIS Geographic Information System. Open Source Geospatial Foundation Project. - Available online at: http://www.qgis.org/.

R Core Team (2015). R: a language and environment for statistical computing. - R Foundation for Statistical Computing, Vienna, Austria. http://www.R-project.org/.

Raxworthy, C., Ingram, C., Rabibisoa, N. and Pearson, R. (2007): Applications of ecological niche modeling for species delimitation: a review and empirical evaluation using day geckos (Phelsuma) from Madagascar. - Syst. Biol. 56(6): 907-923. https://doi.org /10.1080/10635150701775111

Reeves, P. A. and Richards, C. M. (2011): Species delimitation under the general lineage concept: an empirical example using wild North American hops (Cannabaceae: Humulus lupulus). - Syst. Biol. 60(1): 45-59. https://doi.org/10.1093/sysbio/syq056

Richardson, J. L. and Urban, M. C. (2013): Strong selection barriers explain microgeographic adaptation in wild salamander populations. - Evolution. 67(6): 1729-1740. https:// doi.org/10.1111/evo.12052

Rissler, L. and Apodaca, J. (2007): Adding more ecology into species delimitation: ecological niche models and phylogeography help define cryptic species in the Black Salamander (Aneides flavipunctatus). - Syst. Biol. 56(6): 924-942. https://doi.org/10.1080 $/ 10635150701703063$

Rivera, P. C., Di Cola, V., Martínez, J. J., Gardenal, C. N. and Chiaraviglio, M. (2011): Species delimitation in the continental forms of the genus Epicrates (Serpentes, Boidae) integrating phylogenetics and environmental niche models. - PLoS One. 6(9): https:// doi.org/10.1371/journal.pone.0022199

Robarts, D. W. H. and Wolfe, A. D. (2014): Sequence-related amplified polymorphism (SRAP) markers: a potential resource for studies in plant molecular biology (1). Appl. Plant Sci. 2(7): 1-13. https://doi.org/10.3732/apps.1400017

Rosenberg, N. A. (2004): DISTRUCT: a program for the graphical display of population structure. - Mol. Ecol. Notes 4(1): 137-138. https://doi.org/10.1046/j.1471-8286.2003 .00566.x

Rundle, H. D. and Nosil, P. (2005): Ecological speciation. - Ecol. Lett. 8(3): 336-352. https:// doi.org/10.1111/j.1461-0248.2004.00715.x

Schoener, T. W. and Schoener, T. W. (2015): The Anolis lizards of Bimini: resource partitioning in a complex fauna. - Ecology 49(4): 704-726. https://doi.org/10.2307/1935534

Stockwell, D. (1999): The GARP modelling system: problems and solutions to automated spatial prediction. - Int. J. Geogr. Inf. Sci. 13(2): 143-158. https://doi.org/10.1080 /136588199241391

Talebi, M., Rahimmalek, M. and Norouzi, M. (2015): Genetic diversity of Thymus daenensis subsp. daenensis using SRAP markers. - Biologia (Bratislava) 70(4): 453-459. https://doi.org/10.1515/biolog-2015-0059

Tali, M., Abdoli, E. \& Nezammahalleh, M. (2013): Geomorphological and sedimentological evidence of alpine glaciers in the Zagros Mountains, Dinevar, Iran. - J. Tethys 1(1), 85-95.

Thuiller, W., Lafourcade, B., Engler, R. and Araujó, M. B. (2009): BIOMOD - a platform for ensemble forecasting of species distributions. - Ecography 32(3): 369-373. https://doi .org/10.1111/j.1600-0587.2008.05742.x

Vos, P., Hogers, R., Bleeker, M., Reijans, M., van de Lee, T., Hornes, M., Friters, A., Pot, J., Paleman, J., Kuiper, M. and Zabeau, M. (1995): AFLP: a new technique for DNA fingerprinting. - Nucleic Acids Res. 23(21): 4407-4414. https://doi.org/10.1093/nar/23.21.4407

Vroh, B. T. A., Yao, C. Y. A., Kpangui, K. B., Gone Bi, Z. B., Kouame, D., Koffi, K. J. and N. Guessan, K. E. (2016): Comparing suitable habitat models to predict rare and en- 
demic plant species distributions: what are the limits of the niche of Cola lorougnonis (Malvaceae) in Cote d'Ivoire? - Env. Nat. Resour. Res. 6(3): 1-17. https://doi.org/10 .5539/enrr.v6n3p1

Walker, J. B., Sytsma, K. J., Treutlein, J. and Wink, M. (2004): Salvia (Lamiaceae) is not monophyletic: implications for the systematics, radiation, and ecological specializations of Salvia and tribe Mentheae. - Amer. J. Bot. 91(7): 1115-1125. https://doi.org/10 .3732/ajb.91.7.1115

Warren, D. L., Glor, R. E. and Turelli, M. (2010): ENMTools: a toolbox for comparative studies of environmental niche models. - Ecography (Cop.). 33(3): 607-611. https://doi.org /10.1111/j.1600-0587.2009.06142.x

Warren, D. L., Glor, R. E. and Turelli, M. (2008): Environmental niche equivalency versus conservatism: quantitative approaches to niche evolution. - Evolution 62(11): 28682883. https://doi.org/10.1111/j.1558-5646.2008.00482.x

Zhang, Y., Chen, C., Li, L., Zhao, C., Chen, W. and Huang, Y. (2014): Insights from ecological niche modeling on the taxonomic distinction and niche differentiation between the blackspotted and red-spotted Tokay geckoes (Gekko gecko). - Ecol. Evol. 4(17): 3383-3394. https://doi.org/10.1002/ece3.1183

Zheng, H., Fan, L., Milne, R. I., Zhang, L., Wang, Y. \& Mao, K. (2017): Species delimitation and lineage separation history of a species complex of aspens in China. - Frontiers in Plant Science 8: 1-17. https://doi.org/10.3389/fpls.2017.00375 